\title{
Evaluasi Pelaksanaan Kompetensi Berdasarkan Jenjang Karir Profesional Perawat
}

\author{
Nugraha Adi Ramdani Kusumah ${ }^{1}$, Richa Noprianty ${ }^{2}$, Laelasari ${ }^{3}$ \\ Prodi Sarjana Keperawatan, Sekolah Tinggi Ilmu Kesehatan Dharma Husada ${ }^{1,2}$ \\ Prodi Diploma 3 Keperawatan, Sekolah Tinggi Ilmu Kesehatan Dharma Husada ${ }^{3}$ \\ richanoprianty@stikesdhb.ac.id ${ }^{2}$
}

\begin{abstract}
ABSTRAK
Latar Belakang: Rumah sakit di Indonesia sudah mengembangkan jenjang karir sesuai dengan kebutuhan, meskipun belum mengarah pada pengembangan jenjang karir profesional. Jenjang karir digunakan untuk penempatan perawat sesuai dengan keahlian, serta menyediakan kesempatan lebih baik sesuai kemampuan dan potensi perawat. Tujuan: Penelitian ini bertujuan untuk mengetahui evaluasi pelaksanaan kompetensi berdasarkan jenjang karir profesional perawat.

Metode: Desain penelitian deskriptif observasional dengan pendekatan survey. Populasi dalam penelitian ini sebanyak 43 perawat pelaksana, dengan metode total sampling. Instrumen penelitian menggunakan format kewenangan klinis perawat di Rumah Sakit Paru Rotinsulu Bandung yang mengacu kepada kompetensi level karir perawat pada Permenkes RI No. 47 Tahun 2017.
\end{abstract}

Analisa data menggunakan distribusi frekuensi.

Hasil: Pelaksanaan kompetensi berdasarkan jenjang karir profesional perawat dalam kategori sesuai sebesar $58.1 \%$. Pelaksanaan jenjang karir oleh Perawat Klinis I (56.3\%) sesuai, Perawat Klinis II (50.0\%) sesuai, dan Perawat Klinis III (66.7\%) sesuai. Kesimpulan: . Masih banyak perawat yang masuk dalam kategori tidak sesuai, dikarenakan masih banyak juga perawat yang mengerjakan diluar kewenangan, Perawat Klinis I mengerjakan kewenangan Perawat Klinis II dan Perawat Klinis III, begitupun sebaliknya. Hal ini dikarenakan pada saat dinas, pemerataan Perawat Klinis tidak merata. Oleh karena itu, perlu adanya tinjauan ulang dalam segi sumber daya manusia perawat yang sudah memiliki jenjang karir, agar pemerataan jenjang karir yang baik di setiap ruangan.

Kata Kunci: jenjang karir; kompetensi; profesional perawat

\section{ABSTRACT}

Background: Hospitals in Indonesia have developed a career path in accordance with their needs, although not yet leding to the development of professional career paths. Career paths are used for placement of nurses at levels appropriate to their expertise, as well as providing better opportunities according to the abilities and potential of nurses.

Objective: This study aims to determine evaluation of implementation competence based on professional nurse's career path.

Methods: Descriptive observational Study design with survey approach. Population were 43 nurses by total sampling method. Instruments using nurse career guidance guide format created by Dr. H. A. Paru Rotinsulu Bandung Hospital, which refers to the competency level of nurses' care in Permenkes Republic of
Indonesia No. 47 Tahun 2017. Data analysis use frequency distribution.

Results: Implementation of competence based on professional career paths of nurses in inpatient ward in appreciate category of $58.1 \%$. Career path by Clinical Nurse I (56.3\%) was appropriate, Clinical Nurse II (50.0\%) was appropriate, and Clinical Nurse III (66.7\%) was appropriate.

Conclusion: There are still many nurses who fall into unappropriate category, because there are also many nurses who work outside competency, Clinical Nurse I do Clinical Nurse II and Clinical Nurse III, vice versa. This were due at the time of service, Clinical Nurse equitimacy were uneven. Therefore, need review in terms of human resources nurses who already have a career path, for the equalization of good career path in every room.

Keywords: career path; competency; clinical nurses; professional nurse 


\section{PENDAHULUAN}

Rumah sakit sebagai sarana dan fasilitas yang melayani kesehatan mempunyai peran dan fungsi sangat vital dalam usaha meningkatkan derajat kesehatan masyarakat. Berdasarkan Undang - Undang Republik Indonesia nomor 44 tahun 2009 (Depkes, 2009), peran dari rumah sakit adalah menyediakan pelayanan kesehatan secara holistik dan paripurna.

Peraturan Pemerintah RI No. 93/2015 menjelaskan bahwa rumah sakit pendidikan memiliki fungsi sebagai tempat pendidikan, penelitian, dan pelayanan kesehatan secara terpadu dalam bidang pendidikan kedokteran dan/kedokteran gigi, pendidikan berkelanjutan, dan pendidikan kesehatan lainnya secara multiprofesi yang salah satunya adalah pelayanan kesehatan di bidang keperawatan.

Perawat adalah seseorang yang telah lulus pendidikan tinggi keperawatan, baik di dalam maupun di Iuar negeri yang diakui oleh pemerintah sesuai dengan ketentuan Peraturan Perundang-undangan (UUD RI Nomor 38 Tahun 2014). Keberhasilan pemberian asuhan keperawatan ini perlu didukung oleh mekanisme upaya peningkatan profesionalisme perawat. Dalam menentukan kualitas pelayanan pelayanan, perawat harus membentuk motivasi yang kuat sehingga kualitas pekerjaan menjadi lebih baik, salah satunya terkait dengan peningkatan karir.

Jenjang karir profesional merupakan sistem untuk meningkatkan kinerja dan profesionalisme, sesuai dengan bidang pekerjaan melalui peningkatan kompetensi. Pengembangan karir tersebut digunakan untuk penempatan perawat pada jenjang yang sesuai dengan keahliannya, serta menyediakan kesempatan yang lebih baik sesuai dengan kemampuan dan potensi perawat (Menkes, 2017b)

Dampak dari penerapan sistem jenjang karir perawat ada bermacam-macam. (Suroso, 2011) meneliti ada 5 dampak positif berdasarkan riset yang ditimbulkan apabila sistem jenjang karir perawat dapat terlaksana dengan baik, yaitu pengembangan karir, pengakuan, penghargaan, pekerjaan yang menantang, dan promosi, sedangkan dampak apabila tidak dilaksanakannya jenjang karir perawat di rumah sakit akan timbul pada tingkat kepuasan perawat di rumah sakit dan akan memengaruhi motivasi kerja perawat.

Penelitian yang dilakukan oleh Saragih \& Lala (2013) menunjukkan bahwa dari 228 perawat di Rumah Sakit Santo Borromeus diperoleh sebagian responden $(55,7 \%)$ perawat mempunyai jenjang karir yang tidak sesuai sehingga berdampak pada tingkat kepuasan kerja yang rendah. Sebagian kecil mengakui bahwa beban kerja yang PK I lakukan tidak sebanding dengan gaji yang diterima oleh PK II atau III, padahal mereka melakukan kewenangan yang seharusnya dilakukan oleh PK II atau III. Hal tersebut yang menjadi salah satu sumber ketidakpuasan PKI.

Hasil studi pendahuluan yang dilakukan oleh peneliti pada tanggal 3 april 2018 di Rumah Sakit Paru Dr. H. A. Rotinsulu Bandung dengan metode wawancara terhadap enam perawat di tiga ruangan yaitu ruang melati, ruang mawar, dan ruang dahlia, dimana tiga perawat terdiri dari PK I, dua Perawat terdiri dari PK II, dan satu perawat terdiri dari PK III.

Salah satu perawat PK I mengatakan bahwa jenjang karir nya masih belum sesuai, karena dalam pembagian PK di setiap dinasnya masih belum merata, ada yang banyak PK I, ada juga yang banyak di PK II atau III, sehingga dampaknya tidak sesuai dalam melaksanakan asuhan keperawatan. Menurut perawat yang lainnya (PK I) juga mengatakan bahwa kesesuaian dalam menjalankan asuhan keperawatan masih kurang. Ketika dinas tidak seluruhnya terdapat PK II, sehingga jika misalkan terdapat tindakan pemasangan infus, kateter, dan NGT, PK I juga harus bisa melakukan, sedangkan terdapat salah satu perawat PK III mengatakan bahwa jenjang karirnya sudah sesuai karena untuk kewenangan PK III harus bisa mengerjakan kewenangan PKI dan II. 
Jenjang karir perawat yang tidak sesuai dapat berdampak pada kualitas pelayanan. Misalnya, tindakan yang diperuntukan untuk PK III, sedangkan di ruangan tidak ada perawat PK III, jadi mau tidak mau PK I dan II harus bisa mengerjakan. Jika tanpa pelatihan, tentunya akan menimbulkan dampak berupa tindakan yang tidak sesuai dengan SOP. Sehingga, hal tersebut menjadi suatu masalah bagi rumah sakit dalam penerapan jenjang karir.

Berdasarkan permasalahan di atas, maka penulis tertarik melakukan penelitian tentang evaluasi pelaksanaan kompetensi berdasarkan jenjang karir profesional perawat di ruang rawat inap Rumah Sakit Paru Dr. H. A. Rotinsulu Bandung.

\section{METODE}

Jenis penelitian yang digunakan dalam penelitian ini adalah penelitian deskriptif observasional. Populasi dalam penelitian ini adalah seluruh perawat klinis di ruang Mawar, ruang Melati, dan ruang Dahlia Rumah Sakit Paru Dr. H. A. Rotinsulu Bandung yang berjumlah 43 orang perawat. Teknik pengambilan sampel dalam penelitian ini adalah total sampling dengan rincian ruang Dahlia: 10 orang, ruang Melati: 22 orang, dan ruang Mawar: 11 orang.

Pengumpulan data dalam penelitian ini menggunakan teknik observasi pada saat melakukan tindakan sesuai dengan kompetensi di setiap jenjang karirnya. Pengumpulan data menggunakan data primer dan data sekunder. Data primer didapatkan dengan cara peneliti mengobservasi responden yang memenuhi kriteria tertentu dan waktu pelaksanaan minggu ke-1 di bulan April 2018, sedangkan data sekunder didapatkan dengan cara melihat jumlah perawat klinis I sampai dengan III. Pelaksanaan pengumpulan data dibagi menjadi 2 shift, yaitu shift pagi dari jam 07.00-14.00 dan shift sore dari jam 14.00-20.00 dengan mengobservasi PK I, PK II, dan PK III yang sedang melakukan tindakan keperawatan kepada pasien.

Bentuk analisis yang dilakukan pada penelitian ini adalah analisis univariat. Subvariabel dalam penelitian ini adalah evaluasi pelaksanaan kompetensi perawat klinis I, perawat klinis II, dan perawat klinis III. Dalam penelitian ini dilakukan uji normalitas dengan menggunakan uji shapiro wilk karena sampel kurang dari 50 responden. Kriteria uji yaitu jika $p$-value $<0,05$ maka data tersebut berdistribusi normal dan sebaliknya. Berdasarkan hasil uji analisis menggunakan uji normalitas, dapat diketahui bahwa nilai signifikan 0,001 yang berarti tidak normal, sehingga menggunakan nilai median.

\section{HASIL DAN PEMBAHASAN}

Tabel 1. Karakteristik Responden

\begin{tabular}{|c|c|c|c|}
\hline No & Karakteristik & $\mathbf{N}$ & $\%$ \\
\hline \multirow[t]{8}{*}{1} & PK I & & \\
\hline & Jenis Kelamin & & \\
\hline & Laki-Laki & 6 & 37.5 \\
\hline & Perempuan & 10 & 62.5 \\
\hline & Masa Kerja & & \\
\hline & $1-5$ Tahun & 16 & 100 \\
\hline & Pendidikan & & \\
\hline & D3 Keperawatan & 16 & 100 \\
\hline \multirow[t]{11}{*}{2} & PK II & & \\
\hline & Jenis Kelamin & & \\
\hline & Laki-Laki & 4 & 33.3 \\
\hline & Perempuan & 8 & 66.7 \\
\hline & Masa Kerja & & \\
\hline & 1 - 5 Tahun & 5 & 41.7 \\
\hline & 6 - 10 Tahun & 7 & 58.3 \\
\hline & Pendidikan & & \\
\hline & D3 Keperawatan & 10 & 83.3 \\
\hline & S1 Keperawatan & 1 & 8.3 \\
\hline & Ners & 1 & 8.3 \\
\hline \multirow[t]{12}{*}{3} & PK III & & \\
\hline & Jenis Kelamin & & \\
\hline & Laki-Laki & 2 & 13.3 \\
\hline & Perempuan & 13 & 86.7 \\
\hline & Masa Kerja & & \\
\hline & $6-10$ Tahun & 5 & 33.3 \\
\hline & 11 - 15 Tahun & 6 & 40.0 \\
\hline & 16 - 20 Tahun & 3 & 20.0 \\
\hline & 21 - 25 Tahun & 1 & 6.7 \\
\hline & Pendidikan & & \\
\hline & D3 Keperawatan & 13 & 86.7 \\
\hline & Ners & 2 & 13.3 \\
\hline
\end{tabular}

Data pada tabel 1 dapat diketahui bahwa karakteristik jenis kelamin laki-laki yang paling banyak adalah dari PK I dengan jumlah 6 orang atau $37.5 \%$ dan jumlah perempuan yang paling banyak dari PK III dengan jumlah 13 orang atau $86.7 \%$. Pada karakteristik masa kerja yang paling banyak yaitu dari PK I dengan masa 
pelaksanaan jenjang karir. Ruangan yang menerapkan pemerataan PK I akan menghasilkan persentase kesesuaian yang tinggi dibandingkan dengan ruangan yang pemerataan PKI yang tidak seimbang.

Dari rekapitulasi data item lembar observasi didapatkan hasil :

1. Pemenuhan kebutuhan oksigen yang sering dilakukan oleh perawat klinis I adalah terapi oksigen $\left(\mathrm{O}_{2}\right)$. Hal ini dikarenakan latar belakang rumah sakit ini adalah rumah sakit paru, sehingga banyak tindakan-tindakan yang dilakukan oleh perawat terkait dengan terapi oksigen ini.

2. Pemenuhan kebutuhan sirkulasi, cairan, dan nutrisi yang sering dilakukan oleh perawat klinis I yaitu perawatan infus. Hal tersebut dikarenakan banyak pasien yang terpasang infus dan infusan tersebut ada yang mengalami macet, bocor, dan darah yang membeku pada selang infus sehingga harus dilakukan perawatan infus.

3. Pemenuhan kebutuhan eliminasi yang sering dilakukan oleh perawat klinis I yaitu pemasangan kondom kateter. Pada beberapa kasus dilapangan, terdapat pasien yang mengalami kekurangan cairan, sehingga perawat melakukan pemasangan kondom kateter untuk memonitor produksi urin.

4. Pemenuhan kebutuhan mobilisasi/ immobilisasi yang sering dilakukan oleh perawat klinis I yaitu memberikan posisi semi-fowler/fowler. Pada saat dilapangan, peneliti menemukan $3 x$ tindakan perawat klinis I pada pemberian posisi semifowler/fowler pada kasus yang mengalami sesaknafas.

5. Pemenuhan kebutuhan istirahat dan tidur yang banyak dilakukan oleh perawat klinis I yaitu penilaian skala nyeri. Pada kasus dilapangan, peneliti menemukan pasien pasca operasi sehingga perawat melakukan penilaian skala nyeri

6. Pemenuhan kebutuhan personal hygiene dan integument yang sering dilakukan oleh perawat klinis I yaitu tindakan perawatan luka grade I. Kasus yang ditemukan untuk tindakan tersebut yaitu luka decubitus.

7. Pemenuhan kebutuhan suhu normal yang sering dilakukan perawat klinis I yaitu monitoring suhu tubuh. Kasus yang ditemukan dilapangan, terdapat pasien yang mengalami demam, sehingga perawat melakukan monitoring suhu tubuh kepada klien menggunakan termometer digital.

8. Pemenuhan kebutuhan dalam komunikasi yang dilakukan oleh perawat klinis I, yaitu komunikasi terapeutik. Pada saat dilakukan observasi, biasanya pasien yang baru masuk ke ruangan atau baru di pindahkan dari IGD ke ruangan rawat inap dan dilakukan komunikasi terapeutik. Komunikasi terapeutik adalah komunikasi yang dilakukan atau dirancang untuk tujuan terapi.

Hasil ini menunjukkan masih adanya ketimpangan dalam pelaksanaan pemberian pelayanan keperawatan, salah satunya PK I mengerjakan kewenangan PK II atau III tanpa pendampingan. Sebagian kecil mengakui bahwa beban kerja yang PK I lakukan tidak sebanding dengan gaji yang diterima oleh PK II atau 3, padahal mereka melakukan kewenangan yang seharusnya dilakukan oleh PKII atau III. (Kornela Kolibu, dkk, 2017).

Menurut Permenkes RI Nomor 40 tahun 2017, perawat klinis I adalah jenjang perawat klinis dengan kemampuan melakukan asuhan keperawatan dasar dengan penekanan pada keterampilan teknis keperawatan dibawah bimbingan. Dengan kata lain, perawat klinis I hanya diperbolehkan mengerjakan keperawatan dasar.

\section{B. Evaluasi Pelaksanaan Kompetensi Perawat Klinis II}

Pelaksanaan kompetensi yang dilakukan oleh perawat klinis II setengah dari responden (50\%) pelaksanaannya dikategorikan sesuai. Hal tersebut disebabkan karena perawat klinis II dari segi SDM yang ada paling sedikit dibandingkan dengan perawat klinis I dan III. Pemerataan yang terjadi ketika jam dinas 
kerja 1 sampai dengan 5 tahun dengan jumlah 16 orang atau $100 \%$. Pada latar belakang pendidikan keperawatan, yang paling banyak yaitu D3 keperawatan pada PK I dengan jumlah 16 orang atau $100 \%$.

Tabel 2.Evaluasi Pelaksanaan Kompetensi Jenjang Karir Profesional Perawat

\begin{tabular}{llc}
\hline $\begin{array}{c}\text { Kompetensi } \\
\text { Perawat }\end{array}$ & F & \% \\
\hline Sesuai & 25 & 58.1 \\
Tidak Sesuai & 18 & 41.9 \\
\hline \multicolumn{1}{c}{ Total } & $\mathbf{4 3}$ & $\mathbf{1 0 0}$ \\
\hline I & &
\end{tabular}

Diketahui dari tabel 2, bahwa sebagian besar tingkat kesesuaiannya cukup tinggi, yaitu sebesar $58,1 \%$ sesuai. Hal ini disebabkan karena prinsip penerapan kewenangan klinis menunjukan semakin tinggi jenjang karir, maka semakin banyak kewenangan klinis yang harus dikuasai. Hal tersebut ditunjukan pada hasil penelitian, perawat klinis III memiliki persentase yang tinggi pada kategori sesuai, yaitu sebesar $66,7 \%$. Hal tersebut tidak terlepas dari latar belakang pendidikan D3 keperawatan dan juga masa kerja yang memiliki rata-rata 6-25 tahun.

Hasl tersebut sejalan dengan teori (Benner, 1984) dalam_(Suroso, 2011), ada 5 tingkatan, yaitu novice, adv.Beginner, competent, proficient, dan expert.

Hasil distribusi frekuensi yang memiliki tingkat ketidaksesuaian yang paling tinggi yaitu PK II karena pada saat dilakukan observasi masih ada perawat yang mengerjakan diluar kewenangan klinis disebabkan karena keterbatasan jumlah perawat. Tetapi, untuk hasil keseluruhan menunjukkan lebih banyak yang sesuai dengan kewenangan klinis yang sudah ditetapkan pihak rumah sakit, mulai dari kewenangan klinis I, kewenangan klinis II dan kewenangan klinis III.

Penelitian ini tidak sejalan dengan hasil penelitian Saragih \& Lala (2013), dimana tingkat kesesuain jenjang karir perawat di Rumah Sakit Santo Borromeus yang berjumlah 228 responden menunjukan bahwa 101 orang $(44,3 \%)$ sesuai dan 127 orang atau (55,7\%) tidak sesuai. Perbedaan hasil penelitian ini dapat disebabkan karena jenis rumah sakit yang berbeda.

Jenjang karir profesional merupakan sistem untuk meningkatkan kinerja dan profesionalisme sesuai dengan bidang pekerjaan melalui peningkatan kompetensi. Jenjang karir merupakan jalur mobilitas vertikal yang ditempuh melalui peningkatan kompetensi, dimana kompetensi tersebut diperoleh dari pendidikan formal berjenjang, pendidikan informal yang sesuai/relevan maupun pengalaman praktik klinis yang diakui. Dengan arti lain, jenjang karir merupakan jalur untuk peningkatan peran perawat profesional di sebuah institusi (Menkes, 2017).

Rumah sakit dengan penerapan sistem jenjang karir yang sudah sesuai akan memiliki dampak yang baik untuk perawat maupun rumah sakit tersebut. Manfaat penerapan sistem jenjang karir adalah mengembangkan prestasi pegawai, mencegah pegawai minta berhenti karena pindah kerja, meningkatkan loyalitas pegawai, memotivasi pegawai agar dapat mengembangkan bakat dan kemampuannya, mengurangi subjektivitas dalam promosi, memberi kepastian hari depan, mendukung organisasi memperoleh tenaga yang cakap, dan terampil melaksanakan tugas (Hughes, 2013).

Tabel 3.Evaluasi Pelaksanaan Kompetensi Perawat Klinis I, II, dan III

\begin{tabular}{|c|c|c|c|c|c|c|c|}
\hline \multirow{3}{*}{$\begin{array}{l}\text { Kompetensi } \\
\text { Perawat }\end{array}$} & \multicolumn{4}{|c|}{ Kesesuaian } & \multirow{2}{*}{\multicolumn{2}{|c|}{ Total }} & \multirow{3}{*}{ Median } \\
\hline & \multicolumn{2}{|c|}{ Sesuai } & \multicolumn{2}{|c|}{ Tidak } & & & \\
\hline & $\mathbf{F}$ & $\%$ & $\mathbf{F}$ & $\%$ & $\mathrm{~F}$ & $\%$ & \\
\hline PK I & 9 & 56.3 & 7 & 43.7 & 16 & 100 & 16.0 \\
\hline PK II & 6 & 50.0 & 6 & 50.0 & 12 & 100 & 18.0 \\
\hline PK III & 10 & 66.7 & 5 & 33.3 & 15 & 100 & 18.0 \\
\hline
\end{tabular}

\section{A. Evaluasi Pelaksanaan Kompetensi Perawat Klinis I}

Pelaksanaan kompetensi yang dilakukan oleh perawat klinis I sebagian besar pelaksanaan $(56,3 \%)$ dapat dikategorikan sesuai. Hal tersebut ditunjukkan dengan perawat klinis I sudah mengerti dengan kewenangan klinis yang ada, sehingga pada saat pelaksanaannya bisa diaplikasikan dengan baik. Pemerataan PK I disetiap ruangan menjadi salah satu faktor keberhasilan dalam 
kurang begitu sama, sehingga tugas dan kewenangan PK yang diluar kewenangan dikerjakan oleh perawat klinis II. Misalnya, tindakan memenuhi kebutuhan suhu normal pada bagian monitoring dan evaluasi pemberian antipiretik parenteral. Apabila merujuk pada kewenangan klinis, tindakan tersebut seharusnya ditujukan untuk perawat klinis III, tetapi pemerataan yang terjadi diruangan pada saat dinas tidak sama, memunculkan persentase ketidaksesuaian yang cukup tinggi.

Hasil menunjukan pelaksanaan PK II sudah cukup baik. Sebagian responden memiliki persentase $(50 \%)$ yang berarti sesuai dan dijalankan dengan baik. Apabila merujuk kepada karakteristik responden, masa kerja perawat klinis II antara $6-10$ tahun. Dengan masa kerja yang cukup lama dibandingkan perawat klinis I, tentunya perawat klinis II lebih berpengalaman dan mengerti tugas kewenangan yang sudah ditetapkan.

Hasil rekapitulasi data terdapat item lembar observasi, didapatkan hasil:

1. Pemenuhan kebutuhan oksigen yang sering dilakukan oleh perawat klinis II adalah pengambilan sampel AGD. Pada saat dilapangan, peneliti menemukan kondisi pasien yang mempunyai penyakit bronchitis kronik, dan diindikasikan dilakukan pengambilan sampel AGD.

2. Pemenuhan kebutuhan sirkulasi, cairan, dan nutrisi yang sering dilakukan oleh perawat klinis II yaitu perawatan infus. Hal tersebut terjadi karena pemerataan jam dinas yang kurang baik. Seharusnya PK I yang mempunyai kewenangan untuk perawatan infus, tetapi karena SDM yang kurang sehingga PK II yang mengerjakan tindakan tersebut.

3. Pemenuhan kebutuhan eliminasi yang sering dilakukan oleh perawat klinis II yaitu memonitoring dan evaluasi kebutuhan eliminasi. Hal tersebut terjadi ketika perawat klinis III pada saat dinas hanya sedikit, sehingga perawat klinis II yang mengerjakan tugas tersebut.
4. Pemenuhan kebutuhan mobilisasi yang sering dilakukan oleh perawat klinis II adalah mengantar pasien untuk pemeriksaan. Meskipun pekerjaan ini sudah mempunyai pegawai khusus, terkadang perawat yang bertugas pada saat dinas ikut mengantar pasien untuk pemeriksaan. Pada saat observasi dilapangan, peneliti menemukan kondisi pasien yang mengalami efusi pleura dan harus dilakukan pemeriksaan rongent sebagai pemeriksaan lanjutan, dimana perawat klinis II ikut mengantar pasien tersebut dalam pemeriksaan.

5. Pemenuhan kebutuhan istirahat dan tidur yang banyak dilakukan oleh perawat klinis II yaitu yaitu pemberian terapi obat tidur oral. Pada saat dilakukan penelitian, peneliti menemukan pasien yang mengalami sulit untuk tidur, sehingga perawat klinis II pada saat itu memberikan obat tidur kepada pasien.

6. Pemenuhan kebutuhan personal hygiene dan integument yang sering dilakukan oleh perawat klinis II yaitu perawatan luka grade I. Pada saat observasi dilapangan, perawat klinis II berkolaborasi dengan perawat klinis I dalam penanganan personal hygiene kasus pasien decubitus.

7. Pemenuhan kebutuhan suhu normal yang sering dilakukan perawat klinis II yaitu memonitoring dan evaluasi pemberian antipiretik parenteral. Hal tersebut terjadi karena saat jam dinas SDM perawat klinis III kurang, sementara pasien banyak, sehingga pada saat tindakan memonitoring dan evaluasi pemberian antipiretik parenteral dilakukan oleh perawat klinis II.

8. Pemenuhan kebutuhan dalam komunikasi yang dilakukan oleh perawat klinis II yaitu edukasi sesuai dengan masalah klien. Saat dilapangan, peneliti menemukan perawat klinis II yang sedang menjelaskan kondisi dari pasien yang mengalami TB paru.

Hal tersebut sejalan dengan teori From Novice To Expert dari(Benner, 1984), pada level 2 (advance beginner) dalam model dreyfus adalah 
ketika seseorang menunjukan penampilan mengatasi masalah yang dapat diterima pada situasi nyata. Advance beginner mempunyai pengalaman yang cukup untuk memegang suatu situasi. Diperkuat oleh peraturan kewenangan klinis Rumah Sakit Paru Dr. H. A. Rotinsulu Bandung, bahwa tugas PK II yaitu mengerjakan kewenangan klinis II dan juga perawat klinis I. Dengan kata lain, kewenangan klinis I masih dalam kewenangan PK II.

Menurut Permenkes RI No. 17 tahun 2017 (Menkes, 2017), perawat klinis II adalah jenjang perawat klinis dengan kemampuan melakukan asuhan keperawatan holistik pada klien secara mandiri dan mengelola klien/sekelompok klien secara tim serta memperoleh bimbingan untuk penanganan masalah lanjut/kompleks.

\section{Evaluasi Pelaksanaan Kompetensi Perawat Klinik III}

Pelaksanaan kompetensi yang dilakukan oleh perawat klinis III sebagian besar dalam pelaksanaannya $(66,7 \%)$ dapat dikategorikan sesuai. Prinsipnya, semakin tinggi jenjang karir perawat, harus semakin berkompeten yang artinya perawat dengan PK III harus bisa mengerjakan kewenangan klinis mulai dari PK III, PK II, dan juga PK I.

Saat dilakukan observasi hal tersebut terjadi karena salah satu faktor pemerataan PK III disetiap ruangan dan juga jam dinas tidak merata, ditambah dengan mayoritas latar belakang pendidikan D3 keperawatan yang mencapai angka 86,7\% dan pengalaman kerja yang diatas 5 tahun, sehingga persentase yang ditunjukan cukup tinggi.

Hasil rekapitulasi data terdapat item lembar observasi, didapatkan hasil:

1. Pemenuhan kebutuhan oksigen yang sering dilakukan oleh perawat klinis III adalah terapi oksigen. Hal tersebut terjadi karena kondisi pasien tidak ada indikasi dilakukan asuhan keperawatan untuk PK III, dan kondisi pasien lebih mengarah pada pengerjaaan PK II dan PK I.

2. Pemenuhan kebutuhan sirkulasi, cairan, dan nutrisi yang paling sering dilakukan oleh perawat klinis III yaitu tindakan perawatan infus. Hal tersebut terjadi karena kondisi pasien yang lebih banyak mengarah pada kondisi dari pengerjaan PK I, ditambah lagi ada beberapa ruangan yang pemerataan PK I nya kurang, sehingga PK III mengover pekerjaan dari pada PKI

3. Pemenuhan kebutuhan eliminasi yang paling sering dilakukan oleh perawat klinis III yaitu memonitoring \& evaluasi kebutuhan eliminasi. Hal tersebut terjadi karena ada beberapa pasien mengalami dehidrasi sehingga perlu dilakukan monitoring eliminasi.

4. Pemenuhan kebutuhan mobilisasi yang paling sering dilakukan oleh perawat klinis III adalah mengantar pasien untuk pemeriksaan. Hal tersebut terjadi karena pemerataan jam dinas untuk PK I yang kurang merata, sehingga kewenangan klinis I dikerjakan oleh perawat klinis III.

5. Pemenuhan kebutuhan istirahat dan tidur yang paling banyak dilakukan oleh perawat klinis III yaitu tindakan monitoring dan evaluasi kebutuhan istirahat tidur. Hal tersebut terjadi karena ada beberapa pasien yang mengalami kesulitan saat tidur malam, sehingga setelah dilakukan pemberian terapi obat oleh perawat klinis II, dilakukan evaluasi dan juga monitoring terhadap kebutuhan tidur pasien oleh perawat klinis III.

6. Pemenuhan kebutuhan personal hygiene dan integument yang sering dilakukan oleh perawat klinis III yaitu perawatan luka grade I. Hal tersebut terjadi dikarenakan kondisi pasien lebih banyak untuk pengerjaan PK I dan juga pemerataan perawat pada jam dinas dan juga ruangan yang belum merata.

7. Pemenuhan kebutuhan suhu normal yang paling sering dilakukan perawat klinis III yaitu memonitoring dan evaluasi pemberian antipiretik parenteral. Hal tersebut terjadi karena setelah pasien diberikan obat dan dilakukan terapi oleh perawat klinis I dan II, perawat klinis III selanjutnya memonitoring 
dan juga mengevaluasi pemberian obat antipiretik parenteral untuk merencanakan diagnosis yang belum tercapai dan juga untuk menentukan tindakan untuk selanjutnya.

8. Pemenuhan kebutuhan dalam komunikasi yang dilakukan oleh perawat klinis III, yaitu edukasi sesuai dengan masalah klien. Hal tersebut terjadi karena keterbatasan perawat pada saat jam dinas sehingga ketika pada saat pasien pulang, yang memberi tahu kondisi dan juga perawatan di rumah dilakukan oleh perawat klinis III.

Penelitian ini sejalan dengan penelitian yang dilakukan oleh Istirochah \& Santoso (2017) yang menunjukan bahwa kategori praktik keperawatan professional sebagian besar masuk dalam kategori cukup baik, sebesar $51,5 \%$. Pada penelitian ini, salah satu faktor yang menunjang hasil yaitu dari segi masa kerja yang diatas 9 tahun, dengan latar belakang pendidikan D3 keperawatan yang mencapai angka 83,5\%.

Secara teori, terdapat 5 tingkatan perawat klinis, salah satunya yaitu perawat klinis III yang disebutkan didalamnya yaitu kompeten. Artinya, tahap kompeten dari Model Dreyfus ditandai dengan kemampuan mempertimbangkan dan membuat perencanaan yang diperlukan untuk suatu situasi dan sudah dapat dilepaskan. Tahap kompeten ditandai dengan konsisten dan kemampuan memprediksi serta manajemen waktu. Perawat kompeten dapat menunjukkan responsibilitas yang lebih pada respon pasien, lebih realistis dan dapat menampilkan kemampuan kritis pada dirinya.

\section{PENUTUP}

Pengembangan jenjang karir perawat di Rumah Sakit Paru Rotinsulu Bandung sudah diterapkan sejak tahun 2013, akan tetapi untuk uji kredensial dan berdampak ke jasa remunerasi mulai diterapkan tahun 2017. Sampai saat ini, untuk perawat klinis tertinggi ada di PK III. Hasil observasi menunjukkan bahwa masih banyak ketidaksesuaian antara job description dengan pelaksanaan di lapangan. Hal ini dikarenakan beberapa faktor diantaranya adalah ketidaksesuaian pembagian PK pada setiap shift kerja perawat dan tidak merata jumlah PK I, II, dan III di ruangan. Selain itu, masih banyak perawat yang mempunyai persepsi bahwa makin tinggi jenjang karir, maka pekerjaan akan semakin meningkat sehingga perawat merasa kenaikan PK menjadi suatu beban. Hal itu tentu dapat berdampak kepada kepuasan kerja perawat sendiri.

Oleh karena itu, hasil penelitian ini dapat menjadi dasar untuk penelitian selanjutnya untuk meneliti tentang persepsi jenjang karir perawat terhadap kepuasan kerja perawat.

\section{DAFTAR PUSTAKA}

Benner, P. (1984). From Novice To Expert Excellence And Power In Clinical Nursing Practice. AJN, American Journal o f $\quad \mathrm{N}$ u r s i n g. https://doi.org/10.1097/00000446198412000-00025

Andarmoyo, Sulistyo. (2012). Keperawatan Keluarga Konsep Teori, Proses dan Praktik Keperawatan. Yogyakarta: Graha Ilmu.

Depkes. Undang-Undang Republik Indonesia No 44 Tahun 2009 Tentang Rumah Sakit. , Pub. L. No. 44 Tahun 209 (2009).

Hughes, (2005). Elaine. Nurses' perceptions of continuing professional development. Nursing Standart. Vol 19 No. 43, 41-49.

Istirochah, I., \& Santoso, A. (2017). Gambaran Pelaksanaan Praktik Keperawatan Profesional Perawat Klinik III berdasarkan Kewenangan Klinis di Instalasi Rawat Inap Rsup Dr. Kariadi Semarang. Diponegoro University.

Kolibu, F. K., Hariyanto, T., \& Pusparahaju, A. (2014). Pengembangan Model Jenjang Karir Perawat Klinis di Unit Rawat Inap Rumah Sakit. Jurnal Kedokteran Brawijaya, 28(1), 59-64.

Melnyk, B. M., Bernadette; Gallagher-Ford; Long, L.E; Fineout-Overholt. (2014). The 
Establishment of Evidence-Based Practice Competencies for Practicing Registered Nurses and Advanced Practice Nurses in Real-World Clinical Settings: Proficiencies to Improve Healthcare Quality, Reliability, Patient Outcomes, and Costs. Worldviews on Evidence-Based Nursing, 2014; 11:1, 5-15.

Melnyk, B. M., \& Fineout-Overholt, E. (2011). Evidence-based practice in nursing and healthcare. A guide to best practice. Philadelphia, PA: Lippincott, Williams, \& Wilkins.

Melnyk, B. M., Fineout-Overholt, E., GallagherFord, L., \& Kaplan, L. (2012). The state of evidence-based practice in US nurses: Critical implications for nurse leaders and educators. Journal of Nursing Administration, 42(9), 410-417.

Menkes, R. Peraturan Menteri Kesehatan Republik Indonesia Nomor 17 Tahun 2017 Tentang Rencana Aksi Pengembangan Industri Farmasi Dan Alat Kesehatan. , Pub. L. No. 17 Tahun 2017 (2017).

Menkes, R. Peraturan Menteri Kesehatan Republik Indonesia Nomor 40 Tahun 2017 Tentang Pengembangan Jenjang Karir Profesional Perawat Klinis. , Pub. L. No. 40 Tahun 2017 (2017).

Menkes, R. Undang-undang Republik Indonesia Nomor 44 Tahun 2009 tentang Rumah Sakit., Pub. L. No. 44 Tahun 2009 (2009).

Menkes, R. Undang-undang Republik Indonesia Nomor 38 Tahun 2014 tentang Keperawatan, Pub. L. No. 38 Tahun 2014 (2014).

Patrisia, I. (2017). Hubungan antara kualitas kehidupan kerja perawat dengan kepuasan kerja perawat dalam pilot project implementasi jenjang karir Perawat Klinik di RSUP Dr. Hasan Sadikin Bandung. Bandung: Universitas Padjadjaran. Tesis Keperawatan Universitas Padjadjaran.

Pertiwiwati at al. (2016). Peran Educator Perawat Dengan Pelaksanaan Discharge Planning Pada Pasien Di Ruang Tulip 1c RSUD Ulin Banjarmasin. Universitas Lambung Mangkurat. Jurnal Keperawatan 4(2), 82-87.

Potter \& Perry. (2005). Fundamental Of Nursing edisi 7. Jakarta: Salemba Medika.

Rose Kearner \& Nunnery. (2016). Advancing Your Career: Concept of Professional Nursing, Sixth Edition. F. A Davis Company:Philadelphia:USA.

Saragih, S. G., \& Lala, A. (2013). Hubungan jenjang karir dengan kepuasan kerja perawat di Rumah Sakit Santo Borromeus. E-Journal STIKES Santo Borromeus.

Suroso, J. (2011). Penataan Sistem Jenjang Karir Berdasar Kompetensi untuk Meningkatkan Kepuasan Kerja dan Kinerja Perawat di Rumah Sakit. Eksplanasi, 6(2).

Wartonah, Tarwoto. (2010). Kebutuhan Dasar manusia dan Proses Keperawatan. Jakarta. Salemba Medika

Wibowo (2012). Manajemen Kinerja. Jakarta: raja Grafindo Persada.

World Health Organization. (2009). Buku Saku Pelayanan Kesehatan Anak di Rumah Sakit. Switzerland: Geneva.

Yvonne ten Hoeve, Gerard Jansen \& Petrie Roodbol. (2013). The Nursing Profession: Public Image, Self-Concept and Professionalidentity. A Discussion Paper. JAN: Discussion Paper. 296-309. 